\title{
Influence of Physio-Chemical Parameters on Fish Diversity in Muthupet Estuary, Southeast Coast of India
}

\author{
A. Suganthi ${ }^{1}$, C. Venkatraman ${ }^{1}$, B. Bharath ${ }^{2}$, K. Perinbam ${ }^{2 *}$ \\ ${ }^{1}$ Marine Biology Regional Centre, Zoological Survey of India, Chennai, Tamil Nadu, India. \\ ${ }^{2} \mathrm{PG}$ and Research Department of Botany, Government Arts College for Men (Autonomus), Nandanam, Chennai, Affiliated to \\ University of Madras, Tamil Nadu, India. \\ *Corresponding Author: drperinbam73@gmail.com
}

Available online at: www.isroset.org

Accepted: 12/Aug/2018, Online: 30/Aug/ 2018

\begin{abstract}
The present investigation was intended to study the variation between physico-chemical parameters and Fish diversity of Muthupet estuarine. Samples were collected on a monthly basis from January 2014 to December 2015 at Muthupet estuarine. Correlation between fish and physico-chemical parameters such as total rainfall, atmospheric temperature, water temperature, $\mathrm{pH}$, salinity, dissolved oxygen (DO), nitrate, phosphate and silicate were performed. The significant $(\mathrm{P}<0.05)$ variation among seasons as well as a high influence of these parameters was observed on fish diversity. A total of 22 fin fish species were recorded during the study period in Muthupet estuarine. Maximum Percentage of average fish abundance $L$. parsia (11\%) was recorded in the year 2014 and 2015. The diversity index of muthupet estuary indicates that the estuary is less polluted. Present study revealed that physiochemical parameters play a vital role in species distribution.
\end{abstract}

Keywords- Easturine, Physiochemical, Fish, Diversity, Correlation

\section{Introduction}

Coastal wetlands play a significant role as a transition of water body between the land and the sea. Like eateries, they exhibit unique hydrological conditions ranging from fresh water to sea water. Most of them act as a slit trap and facilitate growth of salt marshes and mangroves. Their nutrient richness often enhances productivity and supports good fishery. However, due to human interventions like discharge of untreated sewage and industrial effluents either directly or indirectly through water bodies draining into them. Such activities change the characteristics of the ecosystem [1].

Estuarine and the coastal areas is complex and dynamic aquatic environment. When river water mixes with sea water, large numbers of physical and chemical process take place which may influence the water quality. The health status and biological diversity of Indian estuarine ecosystems are deteriorating day by day through manmade activities such as dumping of domestic sewage and industrial effluents into estuaries which have resulted in the drastic reduction of shallow water fish population and disappearance of numerous fauna and flora [2].

Water is the lifeline for all living organisms on the earth. All terrestrial organisms including human beings have an average of $65 \%$ water as the body constituents [3]. Due to progressive population, increase on one hand and deterioration of the environment on the other, water availability on the global scale has drastically declined. An estimate reveals that if a man lives for a life span of 70 years, they will need at least 750,000 tones of water for his survival [4]. Many studies have been carried out so for on physicochemical parameters of various estuaries of India [5, 6]. In India, 14 major river systems form about $83 \%$ of drainage basin. The total water spread in India is about four million hectares. Inland water bodies are used in aquaculture cover about three million hectares, they include about 0.72 million hectares of natural lakes and 2.28 million hectares of manmade reservoirs [4].

The variations of hydrographical characters in the estuarine ecosystem have deep influence on seasonal occurrence of the juveniles and fish stocks. The changing environment of estuaries i.e., from fresh to marine and marine to fresh have effect on the survival, growth and breeding of fishes. The complete band of the distribution and species composition of juvenile fish in relation to the dynamic changes of hydrographical features of estuaries and fish juveniles are abundantly available in the shallow coastal, estuarine and brackish waters as they are safe from predators and their composition change with seasons [7]. An estuary is a dynamic ecosystem, facilitates mixing of marine and fresh water with high nutrients which provide conductive 
environment for distribution of many fish species [8]. Brackish water basin acts as the breeding, feeding and nursery ground for both fin fish and shell fishes which migrate from either fresh or marine waters [9].

Estuarine environmental study has been advanced during the past two decades, since estuaries support rich pelagic, benthic communities and serve as nurseries for most of the commercial fin and shell fishes [10]. Estuarine environment received much attention during recent years by ecologists around the world. Estuaries constitute an extra ordinary fertile community and they serve as nursery grounds. They also form the centers for natural seed collection of most of the commercially important fin fishes and shell fishes suitable for aquaculture [11].

\section{Materials and Methods}

\section{Sampling}

Muthupet estuary located along the Coromandel Coast is one of the least disturbed ecosystems. It is a marine-coastal wetland with a wide diversity of habitats and ecological features, including intertidal salt marshes, forested wetlands, mangroves and brackish to saline lagoons. Muthupet mangrove is the largest mangrove forest in Tamil Nadu. Water samples, primary production experiments, fish collections were made fortnightly preferably on every full moon and new moon days at Muthupet estuarine for the period of two years. (January 2014 to December 2015) The average values of each month are taken for the present study. The data obtained for two years was discussed in order to find out the seasonal variations in distribution and abundance of fish diversity in relation to environmental parameters.

\section{Physicochemical parameters}

Surface water samples were collected from three different zones of Muthupet mangroves. The rainfall data was obtained from Government Regional Meteorological Department, Chennai. Atmospheric and water temperatures were measured using standard mercury filled centigrade thermometer of $0^{\circ} \mathrm{C}$ to $110^{\circ} \mathrm{C}$. The $\mathrm{pH}$ meter was used to determine the $\mathrm{pH}$. The Mohr-Knudsen titration procedure and Winkler's method was followed for salinity and dissolved oxygen determination respectively. For analysis of nutrients, surface water samples were collected in clean polyethylene bottles and kept in an ice box and transported immediately to the laboratory. The water samples were filtered using a Millipore filtering system and analyzed for total phosphorus, nitrate and silicate by adopting the standard method [12]. Primary productivity was estimated on the basis of changes in dissolved oxygen using light and dark bottle method as described by Strickland and Parsons [13].

\section{Collection and identification of Fishes}

In order to estimate the fishery potential, a cast net measuring $2.5 \mathrm{~m}$ length, with a mesh size varying from 7 $\mathrm{mm}$ at the base and $15 \mathrm{~mm}$ at the apex was employed for the collection of fish throughout the period of study. The net was hauled ten times during every collection at sampling site. The collected specimens were identified up to species level by using the description and keys given by Day [14, 15].

\section{Statistical analysis}

One way ANOVA was performed using DMRT to observe the variation in Physiochemical parameters and nutrients. Correlation data analysis among all the parameters was performed to find out any possible relationship between them.

\section{Results and Discussion}

\section{Physiochemical parameters}

Monthly variation of rainfall in Muthupet mangroves during 2014 shows maximum $317.4 \mathrm{~mm}$ in November and minimum $0.0 \mathrm{~mm}$ in March and June. In the year 2015 maximum rainfall found in the month of November $312.0 \mathrm{~mm}$ and minimum in the month of February $0.0 \mathrm{~mm}$. The average rainfall in the year 2014 is $114.56 \mathrm{~mm}$, whereas the average rainfall in the year 2015 is $133.9 \mathrm{~mm}$. (Table 1). The rainfall was scanty during post monsoon and summer months. Commendable works are available on Muttukadu backwaters [16], Point Calimere costal water [17], Parangipettai coast [18].

In the year 2014 the highest atmospheric temperature was found in May month and lo west in December month, while same temperature was observed in the year 2015. Water temperature was higher in May $31.5^{\circ} \mathrm{C}, 31.9$ and lower in November $25.4^{\circ} \mathrm{C}, 25^{\circ} \mathrm{C}$ during the year 2014 and 2015 , respectively. Similar observations have been reported by Bikash Saha et al. [19] in Sundarbans brackish water; Soundarapandian et al. [20] in Uppanar estuary; Palpandi [21] in Vellar estuary. The $\mathrm{pH}$ of estuarine water is 8.2 in May 2014, whereas 8.3 in May 2015. Generally low pH values were record values during monsoon period and slightly higher values during summer period. Similar seasonal pattern was recorded earlier by Santhanam and Perumal [22], Palpandi [21] in Vellar estuary. Minimum values of $\mathrm{pH}$ during monsoon in the study area may be controlled by the influence of freshwater discharge, rainfall and also due the decomposition of organic matter as stated by Upandhay [23].

Percentage of salinity during 2014 was observed maximum $34.2 \%$ in May and minimum $8.7 \%$ in November. In the year 2015 the maximum salinity was observed in May 34.3\% and minimum in November $9.1 \%$. The intrusion of neritic water and low river discharge may be responsible for high salinity, the monsoonal rain and continuous flow of the freshwater of the rivers may be responsible for low salinity 
in the present study in conformity with the earlier reports from Vellar estuary [21]. Dissolved Oxygen during the year 2014 and 2015 was gradually decreased in summer and increased in monsoon and post monsoon months (Table 1). Similar observations in DO values have also been reported from the Vellar estuary [7], Point Calimere coastal water [17].

\section{Nutrients and Primary productivity}

Nutrients such as nitrate, phosphate and silicate in the estuarine environment would exhibit substantial seasonal variations depending on the rainfall and consumption of nutrients by autotrophs. Maximum nitrate $(4.45 \mu \mathrm{g} / \mathrm{l})$ was present in November (2014) and 4.51 $\mu \mathrm{g} / \mathrm{l}$ in November (2015). The maximum concentration of phosphate $1.95 \mu \mathrm{g} / \mathrm{l}$ (January2014) and 2.02 $\mu \mathrm{g} / \mathrm{l}$ (January 2015) was observed respectively. High concentration of total phosphorus during monsoon season may be due to heavy rainfall, decomposition of particulate organic matter, industrial effluents and from the agricultural discharges from the adjacent lands Nedumaran et al. [24]. Silicate ranged from $28.25 \mu \mathrm{g} / \mathrm{l}$ in May 2014 to $98.74 \mu \mathrm{g} / \mathrm{l}$ in November 2014 whereas in 2015 the silicate ranged from $28.3 \mu \mathrm{g} / \mathrm{l}$ in May to $99.02 \mu \mathrm{g} / \mathrm{l}$ in November. During the year 2014 the gross primary production was found to be high $(152.35 \mathrm{mg}$ $\mathrm{C} / \mathrm{m}^{3} / \mathrm{hr}$ ) in May and low $\left(26.65 \mathrm{mg} \mathrm{C} / \mathrm{m}^{3} / \mathrm{hr}\right)$ in November. Net primary production ranged from $24.32 \mathrm{mg} \mathrm{C} / \mathrm{m}^{3} / \mathrm{hr}$ in November to $145.6 \mathrm{mg} \mathrm{C} / \mathrm{m}^{3} / \mathrm{hr}$ in May.
Gross primary production during 2015 was ranged from $26.51 \mathrm{mg} \mathrm{C} / \mathrm{m}^{3} / \mathrm{hr}$ in November to $151.16 \mathrm{mg} \mathrm{C} / \mathrm{m}^{3} / \mathrm{hr}$ in July. Net primary production ranged from $25.63 \mathrm{mg} \mathrm{C} / \mathrm{m}^{3} / \mathrm{hr}$ in November to $146.23 \mathrm{mg} \mathrm{C} / \mathrm{m}^{3} / \mathrm{hr}$ in May (Table 2). The physicochemical parameters, salinity and nutrients have been recognized as the major factors controlling primary production $[25,26]$.

\section{Fish Diversity}

Monthly variation of fish in Muthupet estuarine identified 22 different species (Figure 1). Percent of average fish abundance in Muthupet showed high percentage in $L$. parsia, M. cephalus and A. commersoni (11\%) followed by M. gulio (9\%) and S. java (9\%). Least percentage was observed in A. sona (1\%) during 2014 respectively. Percent of average fish abundance in the year 2015 shows higher percentage in L. parsia (11\%), followed by M. cephalus (10\%) and A. commersoni (10\%) followed by M. gulio (9\%) and $S$. java (8\%). Lower percentage was observed in Polyrenus sp. (1\%) (Figure 2). A total of 22 fin fish species were recorded during the study period in Muthupet estuarine. But Hossain et al. [27] reported about 161 species collected by different types of net from Naaf river estuary. Decomposing leaves of mangroves attract fin fish and shell fishes because of the enrichment of microbial biomass and nutritional values of decomposing leaves [28]. Durga et al. [29] have studied a check list of ichithyofaunal diversity of Bahuda estuary, Odisha. They have observed 25 fish species under 2 classes, 6 orders and 18 families.
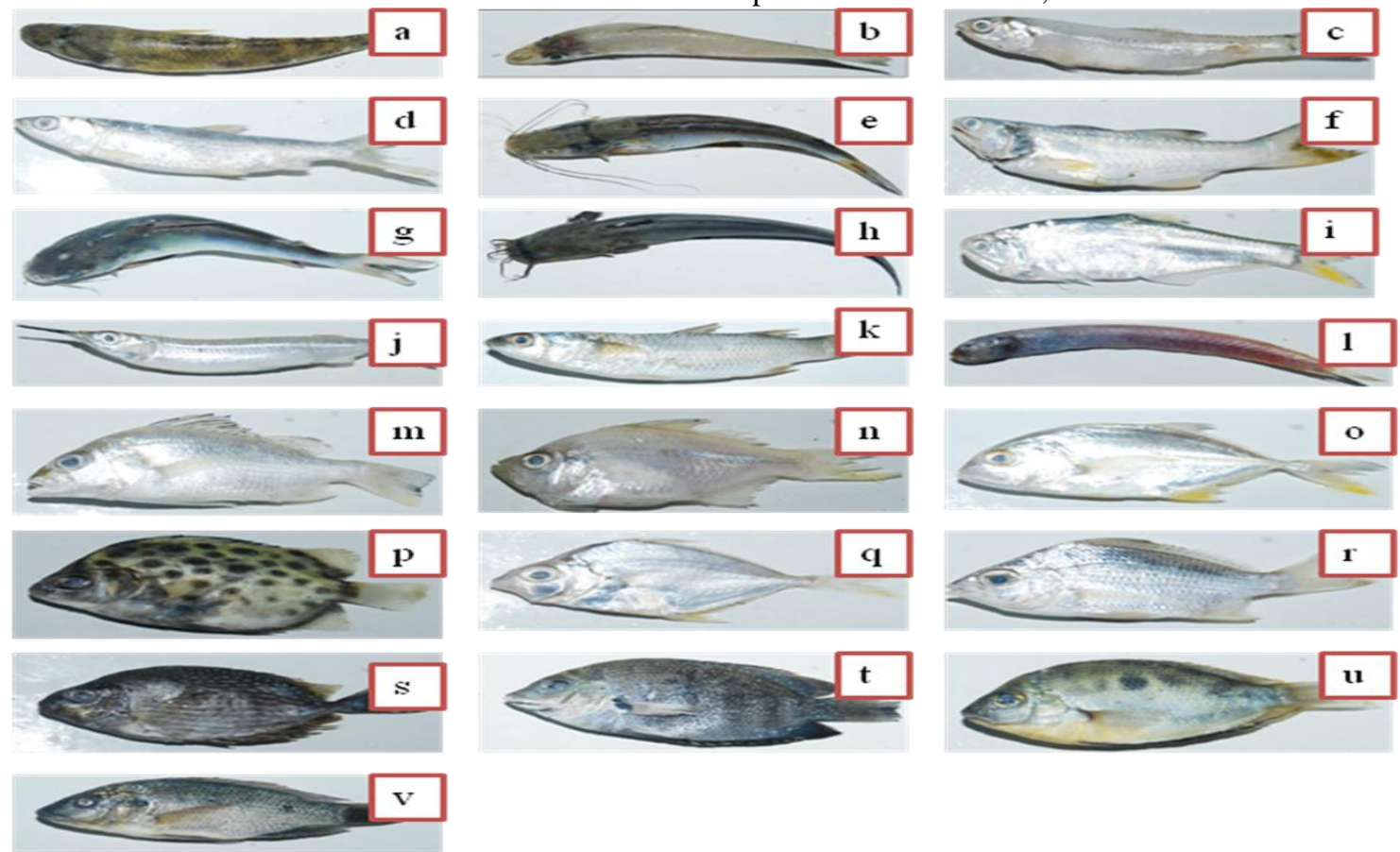

Figure 1: Fish diversity of Muthupet estuary during 2014 and 2015. a: Elotris procephalus, b: Sillago sihama, c: Stolephorus waitei, d: Chanos chanos, e: Arius caelatus, f: Eleutheronema tetradactylum, g: Arius dussumieri, h: Plotosus lineatus, i: Thryssa setirostris, j: Hemiramphus lutlei, k: Moolgarda seheli, 1: Ctenotrypauchen microcephalus, m: Pomadasys kaakan, n: Ambassis gymnocehalus, o: Carangoides caeruleopinnatus, p: Scatophagus argus, q: Leiognathus fasciatus, r: Gerres abbreviatys, s: Siganus avus, t: Etroplus suratensis, u: Etroplus maculates,v: Oreochromis mossambicus 


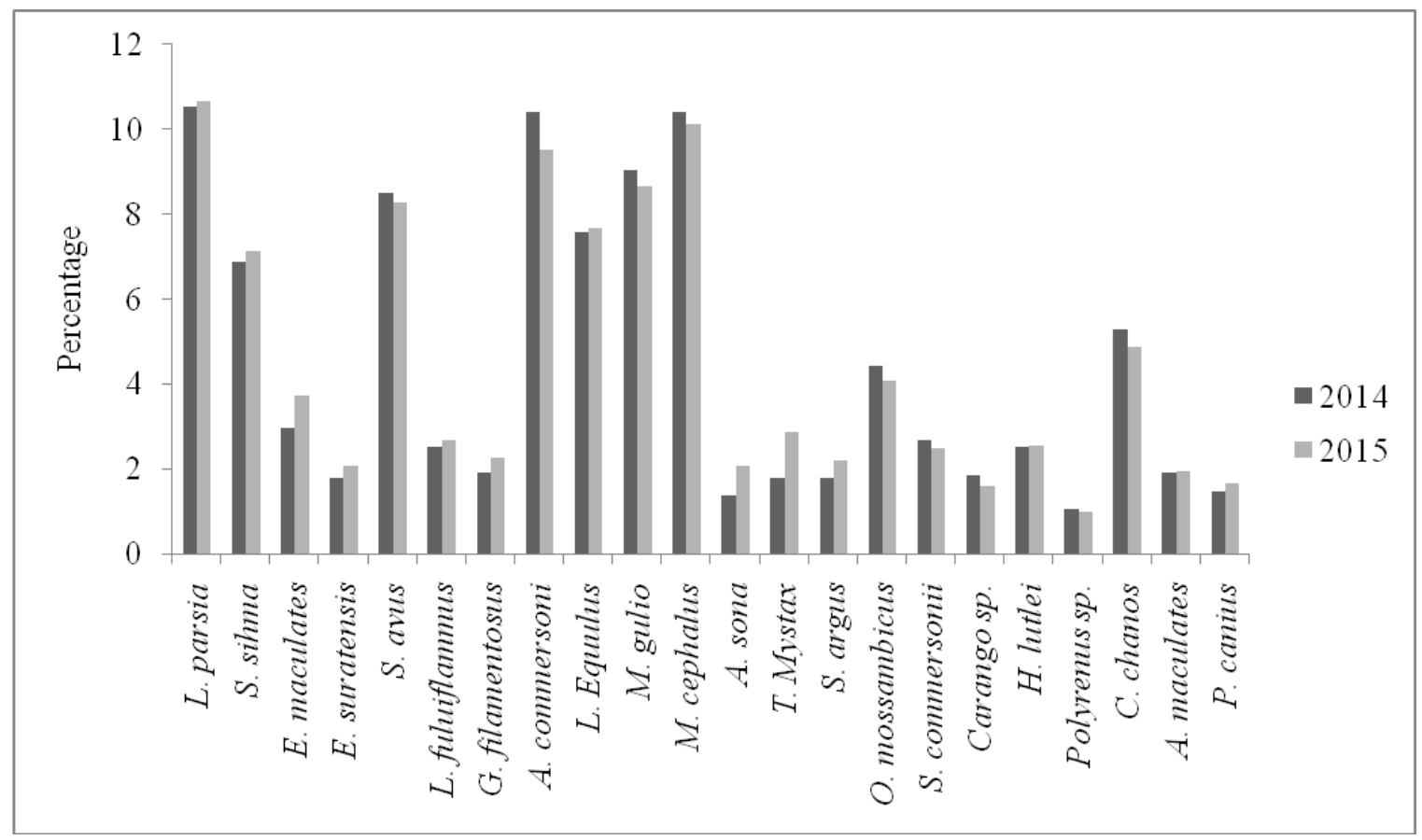

Figure: 2. Percentage of average fish (individuals / m) in Muthupet estuary during 2014 and 2015

\section{Diversity indices}

Diversity indices of fish in Muthupet estuarine during 2014 and 205, the Simpson index ranged from 0.9144 in August to 0.9323 in November, whereas the Shannon index ranged from 2.521 in April to 2.762 in November. The evenness ranged from 0.847 in October to 0.9781 in July (Table 3). Diversity indices of fish in Muthupet estuarine during 2015, the Simpson index ranged from 0.91 in August, September, May and June to 0.93 in October and April, whereas the Shannon index ranged from 2.603 in March to 2.82 in October. The evenness ranged from 0.76 in November and January to 0.82 in April (Table 3). The diversity index indicates good correlation with overall species richness and the biodiversity conservation managers for prioritization of sites of conservation and habitat restoration this is an agreement with previous findings [30-32].

\section{Correlation between Fish and physicochemical parameters}

Correlation between fish and physicochemical parameter total rainfall in 2014 shows positive correlation with most of the fish species. The positively correlated $r$ value ranged from non-significant 0.184 of Plotosus canius to highly significant value of 0.879 of $O$. mossambicus. Whereas in 2015 non-significant of Polyrenus sp. shows nonsignificant value of 0.187 and T. Mystax shows highly significant value of 0.783 . (Table 4). Correlation between fish and atmospheric temperature during the year 2014 showed negative correlation with most of the fish species except L. fuluiflammus, S. argus with non significant value of 0.194 and 0.381 and A. maculates with highly significant value of 0.790. During the year 2015 G. filamentosus and A. maculates shows non-significant value of 0.235 and 0.565 , respectively. $P$. canius shows non-significant value with positive correlation between water temperature in 2014 and 2015, respectively. Blaber [33] reported there is a sudden increase or decrease in water temperature may cause fish mortality.

In the year 2014 and 2015 L. fuluiflammus possess positive correlationbetween fish and $\mathrm{pH}$ with non significant value. Nabi et al. [34] found that $\mathrm{pH}$ plays a vital role in controlling the distribution and abundance of in fish in Bakkhali river estuary. Correlation between fish and salinity, showed negative correlation L. fuluiflammus with non significant and $A$. maculates with significant value in 2014 and 2015. Postive correlation was observed between fish and dissolved oxygen in 2014 and 2015 with some fishes such as A. commersoni, L. fuluiflammus, S. argus, A. maculates and $P$. canius (Table 4). Maes et al. [35] mentioned dissolved oxygen is one of the most important factors for the fish abundance and distribution. Shahadat Hossain et al. [36] observed 53 fish species in the Meghna river estuary and their study revealed that water temperature and rainfall was found as major influential factors for species distribution. In the present study, fin fish population density was maximum during monsoon seasons and minimum during summer. The maximum abundance during monsoon season was already reported by Brinda et al. [7] from Vellar estuary and they concluded that more 
number of species was observed during monsoon season which may prefer low salinity and low temperature. The present findings are in agreement with the above reports.

Correlation of fish species with dissolved nutrients nitrate, phosphate and silicate showed nitrate positive correlation with most of the species except L. fuluiflammus, S. argus, and A. maculates in 2014 and 2015 respectively (Table 5). The positively correlated fish species with nitrate $r$ value in 2014 ranged from 0.281 of $P$. canius to highly significant 0.932 of $S$. commersonii. However in $2015 \mathrm{r}$ value ranged from 0.464 of $G$. filamentosus to highly significant 0.968 of $S$. commersonii. The $\mathrm{r}$ value ranged from 0.134 of $A$. sona to highly significant 0.774 of $M$. gulio are positively correlated with phosphate while in 2015 species $r$ value ranged from 0.037 of $O$. mossambicus to highly significant 0.769 of M. gulio. In 2014, lowest $\mathrm{r}$ value was found in $P$. canius (0.463) and highest in $S$. java $(0.962)$ are positively correlated with silicate as well as in 2015 G. filamentosus (0.259) has lowest $r$ value and $A$. sona $(0.921)$ has highest $r$ value. High nitrate and phosphate concentration in Kangimi reservoir during rainy season coincides with peak surface runoff. The over water quality parameters indicated that water is suitable for fish life in the reservoir [37].

Gross primary productivity showed positive correlation of L. fuluiflammus, S. argus and A. maculates with significant $r$ value $0.735,0.674$ and 0.566 in 2014 (Table 6). At the same time net primary productivity showed positive correlation with L. fuluiflammus and S. argus with significant $r$ value 0.709 and 0.684 . In the year 2015 gross primary productivity showed positive correlation with $S$. argus and A. maculates with $\mathrm{r}$ value of 0.104 and 0.503 . While the net primary productivity showed positive correlation with L. fuluiflammus, S. argus and A. maculates with $\mathrm{r}$ value $0.473,0.021$ and 0.457 , respectively.

Table: 1. Physicochemical parameters recorded from Muthupet estuary during study period 2014 and 2015

\begin{tabular}{|c|c|c|c|c|c|c|c|c|c|c|c|c|}
\hline \multirow{2}{*}{$\begin{array}{l}\text { Parameters } \\
\text { Month/Year }\end{array}$} & \multicolumn{2}{|c|}{$\begin{array}{l}\text { Total Rainfall } \\
\qquad(\mathbf{m m})\end{array}$} & \multicolumn{2}{|c|}{$\begin{array}{c}\text { Atmospheric } \\
\text { Temperature }\left({ }^{\circ} \mathbf{C}\right)\end{array}$} & \multicolumn{2}{|c|}{$\begin{array}{c}\text { Water } \\
\text { Temperature } \\
\left({ }^{\circ} \mathbf{C}\right)\end{array}$} & \multicolumn{2}{|c|}{ pH } & \multicolumn{2}{|c|}{ Salinity (\%) } & \multicolumn{2}{|c|}{$\begin{array}{r}\text { Dissolved } \\
\text { Oxygen }(\mathrm{ml} / \mathrm{l})\end{array}$} \\
\hline & 2014 & 2015 & 2014 & 2015 & 2014 & 2015 & 2014 & 2015 & 2014 & 2015 & 2014 & 2015 \\
\hline January & 20.6 & 20.6 & 30.4 & 30.7 & 29.5 & 30.1 & 7.3 & 7.1 & 10.5 & 10.6 & 5.8 & 6.0 \\
\hline February & 64.4 & 0.0 & 30.2 & 30.8 & 30.2 & 30.8 & 7.8 & 7.6 & 17.5 & 17.8 & 4.5 & 5.1 \\
\hline March & 0.0 & 189.2 & 33.4 & 34.0 & 28.4 & 29.0 & 7.5 & 7.6 & 20.8 & 21.0 & 4.3 & 5.2 \\
\hline April & 3.0 & 116.0 & 34.5 & 35.2 & 30.5 & 31.0 & 7.7 & 7.8 & 31 & 32.8 & 4.5 & 4.9 \\
\hline May & 220.4 & 132.2 & 35.6 & 36.1 & 31.5 & 31.9 & 8.2 & 8.3 & 34.2 & 34.3 & 4.9 & 5.3 \\
\hline June & 0.0 & 77.6 & 33.4 & 33.2 & 31.3 & 31.0 & 7.8 & 8.1 & 28.5 & 29.1 & 3.5 & 4.1 \\
\hline July & 13.4 & 24.0 & 31.6 & 31.2 & 28.2 & 29.1 & 7.8 & 7.9 & 30.5 & 30.2 & 4.7 & 5.0 \\
\hline August & 91.6 & 45.2 & 32.5 & 32.1 & 28.2 & 28.4 & 7.4 & 7.5 & 14.5 & 14.9 & 6.5 & 6.2 \\
\hline September & 76.6 & 238.6 & 31.1 & 30.8 & 27.4 & 27.1 & 7.3 & 7.3 & 14.7 & 14.6 & 5.5 & 5.0 \\
\hline October & 305.7 & 140.7 & 30.2 & 30.0 & 28.3 & 28.7 & 7.2 & 7.3 & 9.5 & 10.0 & 6.8 & 7.0 \\
\hline November & 317.4 & 312.0 & 30.2 & 29.9 & 25.4 & 25.0 & 7.2 & 7.1 & 8.7 & 9.1 & 7.2 & 7.1 \\
\hline December & 261.6 & 310.8 & 28.8 & 27.9 & 27.6 & 26.9 & 7.1 & 7.4 & 9.2 & 9.7 & 6.1 & 6.3 \\
\hline
\end{tabular}

Table: 2. Dissolved Nutrients and Primary Production recorded from Muthupet estuary during study period

\begin{tabular}{|c|c|c|c|c|c|c|c|c|c|c|}
\hline Nutrients & \multicolumn{2}{|c|}{ Nitrate $((\mu \mathrm{g} / \mathrm{l}))$} & \multicolumn{2}{|c|}{ Phosphate $(\mu \mathrm{g} / \mathrm{l}))$} & \multicolumn{2}{|c|}{ Silicate $(\mu \mathrm{g} / \mathrm{l})$} & \multicolumn{2}{|c|}{\begin{tabular}{|c}
$\begin{array}{c}\text { Gross Primary Production } \\
\left(\mathbf{m g ~ C} / \mathbf{m}^{3} / \mathbf{h r}\right)\end{array}$ \\
\end{tabular}} & \multicolumn{2}{|c|}{$\begin{array}{c}\text { Net Primary Production } \\
\left(\mathbf{m g ~ C} / \mathbf{m}^{\mathbf{3}} / \mathbf{h r}\right)\end{array}$} \\
\hline Month/Year & 2014 & 2015 & 2014 & 2015 & 2014 & 2015 & 2014 & 2015 & 2014 & 2015 \\
\hline January & 2.52 & 2.56 & 1.95 & 2.02 & 69.25 & 70.01 & 35.40 & 36.12 & 38.35 & 38.42 \\
\hline February & 1.92 & 1.97 & 1.23 & 1.36 & 49.15 & 49.16 & 34.10 & 34.64 & 36.40 & 37.01 \\
\hline
\end{tabular}




\begin{tabular}{|l|c|c|c|c|c|c|c|c|c|c|}
\hline March & 2.28 & 2.31 & 0.88 & 0.91 & 38.64 & 39.12 & 38.45 & 39.21 & 42.18 & 41.82 \\
\hline April & 1.65 & 1.72 & 0.77 & 0.83 & 30.15 & 30.10 & 84.50 & 84.20 & 65.32 & 65.14 \\
\hline May & 1.45 & 1.55 & 0.58 & 0.50 & 28.25 & 28.30 & 152.35 & 148.59 & 145.6 & 146.23 \\
\hline June & 1.27 & 1.31 & 0.29 & 0.26 & 35.15 & 35.10 & 95.32 & 96.74 & 82.50 & 82.50 \\
\hline July & 1.35 & 1.39 & 0.44 & 0.49 & 33.75 & 34.10 & 149.60 & 151.16 & 125.62 & 126.17 \\
\hline August & 1.96 & 2.01 & 1.15 & 1.40 & 65.25 & 65.50 & 64.35 & 64.20 & 38.65 & 39.56 \\
\hline September & 2.23 & 2.32 & 1.30 & 1.35 & 54.24 & 55.05 & 33.40 & 32.98 & 27.62 & 26.81 \\
\hline October & 4.25 & 4.35 & 1.45 & 1.52 & 80.15 & 79.89 & 28.32 & 29.18 & 28.62 & 28.51 \\
\hline November & 4.45 & 4.51 & 1.15 & 1.20 & 98.74 & 99.02 & 26.65 & 26.51 & 24.32 & 25.63 \\
\hline December & 3.45 & 3.32 & 1.63 & 1.68 & 81.17 & 81.30 & 32.35 & 32.69 & 28.15 & 29.21 \\
\hline
\end{tabular}

Table: 3. Diversity Indices of fish in Muthupet estuary during 2014-20

\begin{tabular}{|c|c|c|c|c|c|c|c|c|c|c|c|c|c|c|c|c|c|c|c|c|c|c|c|c|}
\hline \multirow{2}{*}{ Month } & \multicolumn{2}{|c|}{ Jan } & \multicolumn{2}{|c|}{ Feb } & \multicolumn{2}{|c|}{ Mar } & \multicolumn{2}{|c|}{ Apr } & \multicolumn{2}{|c|}{ May } & \multicolumn{2}{|c|}{ Jun } & \multicolumn{2}{|c|}{ Jul } & \multicolumn{2}{|c|}{ Aug } & \multicolumn{2}{|c|}{ Sept } & \multicolumn{2}{|c|}{ Oct } & \multicolumn{2}{|c|}{ Nov } & \multicolumn{2}{|c|}{ Dec } \\
\hline & 2014 & 2015 & 2014 & 2015 & 2014 & 2015 & 2014 & 2015 & 2014 & 2015 & 2014 & 2015 & 2014 & 2015 & 2014 & 2015 & 2014 & 2015 & 2014 & 2015 & 2014 & 2015 & 2014 & 2015 \\
\hline Simpson_D & 0.91 & 0.92 & 0.92 & 0.92 & 0.91 & 0.91 & 0.91 & 0.93 & 0.91 & 0.91 & 0.91 & 0.91 & 0.91 & 0.92 & 0.91 & 0.91 & 0.91 & 0.91 & 0.92 & 0.93 & 0.93 & 0.92 & 0.93 & 0.92 \\
\hline Shannon_H & 2.55 & 2.78 & 2.58 & 2.74 & 2.52 & 2.60 & 2.52 & 2.79 & 2.53 & 2.62 & 2.54 & 2.55 & 2.54 & 2.75 & 2.50 & 2.73 & 2.53 & 2.69 & 2.66 & 2.82 & 2.76 & 2.78 & 2.74 & 2.78 \\
\hline Evenness_H/S & 0.86 & 0.76 & 0.87 & 0.81 & 0.96 & 0.79 & 0.95 & 0.82 & 0.96 & 0.81 & 0.97 & 0.80 & 0.97 & 0.78 & 0.94 & 0.69 & 0.97 & 0.70 & 0.84 & 0.80 & 0.93 & 0.76 & 0.91 & 0.77 \\
\hline
\end{tabular}

Table: 4. Correlation between Fish and physicochemical parameters of Muthupet estuary during 2014 and 2015

\begin{tabular}{|c|c|c|c|c|c|c|c|c|c|c|c|c|}
\hline \multirow[t]{2}{*}{ Species } & \multicolumn{2}{|c|}{ Total Rainfall } & \multicolumn{2}{|c|}{$\begin{array}{l}\text { Atmospheric } \\
\text { Temperature }\end{array}$} & \multicolumn{2}{|c|}{$\begin{array}{c}\text { Water } \\
\text { Temperature }\end{array}$} & \multicolumn{2}{|c|}{$\mathbf{p H}$} & \multicolumn{2}{|c|}{ Salinity } & \multicolumn{2}{|c|}{$\begin{array}{l}\text { Dissolved } \\
\text { Oxygen }\end{array}$} \\
\hline & 2014 & 2015 & 2014 & 2015 & 2014 & 2015 & 2014 & 2015 & 2014 & 2015 & 2014 & 2015 \\
\hline L. parsia & $\begin{array}{l}0.769 \\
* *\end{array}$ & $0.639 *$ & $-0.726 * *$ & $-0.750 * *$ & $-0.721 * *$ & $-0.769 * *$ & $\begin{array}{l}-0.791 \\
* *\end{array}$ & -0.559 & $\begin{array}{l}-0.772 \\
* *\end{array}$ & $\begin{array}{l}-0.729 \\
* *\end{array}$ & $0.812 * *$ & $0.723 * *$ \\
\hline S.sihma & $\begin{array}{l}0.769 \\
* *\end{array}$ & 0.397 & -0.551 & -0.498 & -0.384 & -0.308 & $-0.596 *$ & -0.321 & $-0.590 *$ & -0.506 & $0.611 *$ & $0.578 *$ \\
\hline E. maculates & $\begin{array}{l}0.730 \\
* *\end{array}$ & 0.423 & -0.475 & -0.456 & -0.457 & -0.365 & -0.551 & -0.189 & -0.453 & -0.356 & 0.508 & $0.598 *$ \\
\hline E. suratensis & $\begin{array}{l}0.799 \\
* *\end{array}$ & 0.382 & -0.660 & $-0.785 * *$ & $-0.819 * *$ & -0.602 & $-0.759 *$ & -0.604 & $-0.736 *$ & $-0.722 *$ & $0.800 * *$ & $0.839 * *$ \\
\hline
\end{tabular}




\begin{tabular}{|c|c|c|c|c|c|c|c|c|c|c|c|c|}
\hline S. java & $\begin{array}{l}0.790 \\
* *\end{array}$ & $0.624 *$ & $-0.693 *$ & $-0.643 *$ & $-0.755 * *$ & $-0.792 * *$ & $\begin{array}{l}-0.805 \\
* *\end{array}$ & $-0.655 *$ & $\begin{array}{l}-0.822 \\
* *\end{array}$ & $\begin{array}{l}-0.731 \\
* *\end{array}$ & $0.917 * *$ & $0.823 * *$ \\
\hline L. fuluiflammus & -0.033 & -0.059 & 0.194 & -0.077 & 0.106 & -0.141 & 0.499 & 0.296 & 0.556 & 0.331 & -0.275 & -0.089 \\
\hline G. filamentosus & 0.456 & 0.090 & -0.272 & 0.235 & -0.401 & -0.077 & -0.479 & -0.236 & -0.512 & -0.190 & 0.574 & 0.527 \\
\hline A. commersoni & $\begin{array}{l}0.811 \\
* *\end{array}$ & $0.595 *$ & $-0.619 *$ & $-0.659 *$ & -0.771 ** & $-0.817 * *$ & $\begin{array}{l}-0.724 \\
* *\end{array}$ & $-0.623 *$ & $\begin{array}{l}-0.708 \\
* *\end{array}$ & $-0.703 *$ & $0.924 * *$ & $0.895 * *$ \\
\hline L. Equulus & $\begin{array}{l}0.771 \\
* *\end{array}$ & $0.658 *$ & $-0.666 *$ & $-0.586 *$ & $-0.825 * *$ & $-0.784 * *$ & $-0.659 *$ & $-0.596 *$ & $-0.698 *$ & $-0.682 *$ & $0.739 * *$ & $0.812 * *$ \\
\hline M. gulio & 0.536 & 0.448 & $-0.808 * *$ & $-0.745 * *$ & $-0.706 *$ & $-0.652 *$ & $\begin{array}{l}-0.892 \\
* *\end{array}$ & $\begin{array}{l}-0.796 \\
* *\end{array}$ & $\begin{array}{l}-0.892 \\
* *\end{array}$ & $\begin{array}{l}-0.806 \\
* *\end{array}$ & $0.728 * *$ & $0.813 * *$ \\
\hline M. cephalus & $\begin{array}{l}0.727 \\
* *\end{array}$ & $\begin{array}{l}0.774 \\
* *\end{array}$ & -0.563 & $-0.578 *$ & $-0.807 * *$ & $-0.851 * *$ & $\begin{array}{l}-0.734 \\
* *\end{array}$ & -0.537 & $-0.643 *$ & $-0.592 *$ & $0.693^{*}$ & $0.732 * *$ \\
\hline A. sona & $\begin{array}{l}0.844 \\
* *\end{array}$ & $0.729 *$ & -0.454 & $-0.808 * *$ & $-0.775 *$ & $-0.893 * *$ & $-0.707 *$ & $-0.756 *$ & -0.566 & $\begin{array}{l}-0.804 \\
* *\end{array}$ & 0.661 & $0.807 * *$ \\
\hline T. Mystax & $0.749 *$ & $\begin{array}{l}0.783 \\
* *\end{array}$ & -0.473 & $-0.641 *$ & -0.348 & -0.600 & -0.614 & -0.337 & -0.479 & -0.535 & 0.428 & 0.487 \\
\hline S. argus & -0.423 & 0.022 & 0.381 & -0.177 & $0.696^{*}$ & 0.044 & $0.680 *$ & 0.178 & $0.748 *$ & 0.186 & $-0.673 *$ & -0.164 \\
\hline $\begin{array}{l}O . \\
\text { mossambicus }\end{array}$ & $\begin{array}{l}0.879 \\
* *\end{array}$ & 0.706 & -0.723 & $-0.852 *$ & -0.502 & -0.583 & -0.726 & -0.345 & $-0.854 *$ & $-0.828 *$ & 0.599 & $0.760 *$ \\
\hline S. commersonii & $0.696 *$ & $0.678 *$ & -0.610 & -0.507 & $-0.751 *$ & $-0.727 *$ & $-0.670 *$ & $-0.688 *$ & $-0.708 *$ & $-0.645 *$ & $0.800 * *$ & $0.827 * *$ \\
\hline C. species & $\begin{array}{l}0.836 \\
* *\end{array}$ & $0.764 *$ & $-0.674 *$ & -0.628 & $-0.655 *$ & $-0.740 *$ & $-0.684 *$ & -0.492 & $-0.745 *$ & -0.566 & $0.778 * *$ & 0.628 \\
\hline H. species & $0.645 *$ & 0.195 & -0.424 & -0.516 & $-0.741 * *$ & -0.375 & $-0.689 *$ & -0.395 & -0.560 & -0.462 & 0.812 ** & $0.731 * *$ \\
\hline P. species & 0.458 & 0.187 & $-0.667 *$ & -0.651 & $-0.789 *$ & -0.641 & -0.543 & -0.591 & -0.536 & -0.583 & 0.505 & $0.832 * *$ \\
\hline C. chanos & $\begin{array}{l}0.765 \\
* *\end{array}$ & 0.417 & -0.430 & -0.444 & $-0.626 *$ & $-0.660 *$ & -0.504 & -0.563 & -0.498 & -0.574 & $0.779 * *$ & $0.898 * *$ \\
\hline A. maculates & -0.251 & -0.270 & $0.790 * *$ & 0.565 & $0.633 *$ & 0.547 & 0.513 & 0.464 & $0.775 * *$ & $0.725 *$ & -0.556 & -0.563 \\
\hline P. canius & 0.184 & -0.530 & -0.620 & -0.187 & 0.451 & 0.514 & -0.014 & -0.305 & -0.519 & -0.286 & 0.131 & -0.044 \\
\hline
\end{tabular}

$* *$ Correlation is significant at the 0.01 level (2-tailed). *Correlation is significant at the 0.05 level (2-tailed).

Table: 5. Correlation between Fishes and Nutrients of Muthupet estuary during 2014 and 2015

\begin{tabular}{|l|c|c|c|c|c|c|}
\hline \multirow{2}{*}{ Fish Species } & \multicolumn{2}{c|}{ Nitrate } & \multicolumn{2}{c|}{ Phosphate } & \multicolumn{2}{c|}{ Silicate } \\
\cline { 2 - 7 } & $\mathbf{2 0 1 4}$ & $\mathbf{2 0 1 5}$ & $\mathbf{2 0 1 4}$ & $\mathbf{2 0 1 5}$ & $\mathbf{2 0 1 4}$ & $\mathbf{2 0 1 5}$ \\
\hline L. parsia & $0.815 * *$ & $0.712 * *$ & $0.583 *$ & 0.545 & $0.879 * *$ & $0.823 * *$ \\
\hline S. sihma & $0.717 * *$ & $0.580 *$ & 0.541 & 0.421 & $0.725 * *$ & $0.618 *$ \\
\hline E. maculates & $0.745 * *$ & $0.657 *$ & 0.197 & 0.156 & $0.614 *$ & 0.541 \\
\hline E. suratensis & $0.928 * *$ & $0.774 * *$ & 0.563 & 0.550 & $0.889 * *$ & $0.839 * *$ \\
\hline S. java & $0.905 * *$ & $0.820 * *$ & $0.596 *$ & 0.515 & $0.962 * *$ & $0.922 * *$ \\
\hline L. fuluiflammus & -0.288 & -0.208 & -0.540 & -0.385 & -0.425 & -0.238 \\
\hline G. filamentosus & $0.700 *$ & 0.464 & 0.485 & 0.067 & 0.498 & 0.259 \\
\hline A. commersoni & $0.875 * *$ & $0.885 * *$ & 0.476 & 0.451 & $0.878 * *$ & $0.879 * *$ \\
\hline L. Equulus & $0.805 * *$ & $0.869 * *$ & 0.427 & 0.385 & $0.820 * *$ & $0.822 * *$ \\
\hline M. gulio & $0.863 * *$ & $0.777 * *$ & $0.774 * *$ & $0.769 * *$ & $0.895 * *$ & $0.875 * *$ \\
\hline M. cephalus & $0.844 * *$ & $0.848 * *$ & 0.317 & 0.260 & $0.778 * *$ & $0.796 * *$ \\
\hline
\end{tabular}




\begin{tabular}{|l|c|c|c|c|c|c|}
\hline A. sona & $0.830 *$ & $0.867 * *$ & 0.134 & 0.604 & $0.845 * *$ & $0.921 * *$ \\
\hline T. Mystax & $0.679 *$ & $0.691 *$ & 0.228 & 0.243 & $0.664 *$ & $0.641 *$ \\
\hline S. argus & -0.578 & -0.030 & -0.548 & -0.233 & -0.635 & -0.038 \\
\hline O. mossambicus & $0.856 *$ & $0.845 *$ & 0.226 & 0.037 & $0.828 *$ & $0.862 *$ \\
\hline S. commersonii & $0.932 * *$ & $0.968 * *$ & 0.378 & 0.256 & $0.838 * *$ & $0.826 * *$ \\
\hline C. species & $0.917 * *$ & $0.784 *$ & 0.599 & 0.168 & $0.929 * *$ & $0.757 *$ \\
\hline H. species & $0.716 * *$ & $0.689 *$ & 0.385 & 0.386 & $0.657 *$ & $0.577 *$ \\
\hline P. species & 0.611 & $0.709 *$ & 0.359 & 0.432 & $0.671 *$ & $0.803 * *$ \\
\hline C. chanos & $0.829 * *$ & $0.848 * *$ & 0.253 & 0.357 & $0.716 * *$ & $0.797 * *$ \\
\hline A. maculates & -0.462 & -0.554 & $-0.674 *$ & -0.405 & $-0.675 *$ & $-0.658 *$ \\
\hline P. canius & 0.281 & -0.113 & 0.644 & 0.497 & 0.463 & 0.127 \\
\hline
\end{tabular}

**Correlation is significant at the 0.01 level (2-tailed). *Correlation is significant at the 0.05 level (2-tailed).

Table: 6. Correlation between Fishes and Productivity of Muthupet estuary during 2014 and 2015

\begin{tabular}{|c|c|c|c|c|}
\hline \multirow[t]{2}{*}{ Species } & \multicolumn{2}{|c|}{ Gross Primary Production } & \multicolumn{2}{|c|}{ Net Primary Production } \\
\hline & 2014 & 2015 & 2014 & 2015 \\
\hline L. parsia & -0.509 & -0.490 & -0.535 & -0.524 \\
\hline S.sihma & -0.398 & -0.239 & -0.363 & -0.195 \\
\hline E. maculates & -0.330 & -0.237 & -0.344 & -0.238 \\
\hline E. suratensis & -0.611 & -0.473 & -0.580 & -0.458 \\
\hline S. java & $-0.591 *$ & -0.531 & $-0.620 *$ & -0.555 \\
\hline L. fuluiflammus & $0.735 *$ & 0.549 & $0.709 *$ & 0.473 \\
\hline G. filamentosus & -0.531 & -0.257 & -0.488 & -0.252 \\
\hline A. commersoni & -0.438 & -0.469 & -0.482 & -0.500 \\
\hline L. Equulus & -0.443 & -0.468 & -0.418 & -0.398 \\
\hline M. gulio & $-0.729 * *$ & -0.555 & $-0.693 *$ & -0.527 \\
\hline M. cephalus & -0.485 & -0.454 & -0.506 & -0.469 \\
\hline A. sona & -0.366 & $-0.712 *$ & -0.403 & $-0.684 *$ \\
\hline T. Mystax & -0.345 & -0.436 & -0.354 & -0.415 \\
\hline S. argus & $0.674 *$ & 0.104 & $0.684 *$ & 0.021 \\
\hline O. mossambicus & -0.484 & -0.510 & -0.637 & -0.598 \\
\hline S. commersonii & $-0.633 *$ & -0.518 & -0.611 & -0.483 \\
\hline C. species & -0.537 & -0.531 & -0.528 & -0.485 \\
\hline H. species & -0.374 & -0.176 & -0.438 & -0.171 \\
\hline P. species & -0.435 & -0.287 & -0.395 & -0.333 \\
\hline C. chanos & -0.299 & -0.353 & -0.310 & -0.354 \\
\hline A. maculates & 0.566 & 0.503 & 0.534 & 0.457 \\
\hline P. canius & -0.464 & -0.345 & -0.379 & -0.246 \\
\hline
\end{tabular}

**Correlation is significant at the 0.01 level (2-tailed). *Correlation is significant at the 0.05 level (2-tailed). 


\section{Conclusion and Future scope}

Economically and ecologically estaurines plays a major role in fish diversity resource. The physicochemical parameters such as temperature, $\mathrm{pH}$, salinity and dissolved oxygen are the most important factors triggering the fin fish species distribution in Muthupet estuary. Furthuer studies need to carried out the biochemical profile of fishes. These studies are helful to conserve and management of estuarines to increase the species distributions and sustainable production.

\section{Disclosure statement}

The authors declared that we have no potential conflict of interest

\section{References}

[1]. Balakrishna, N.N., M. Arunachalam, A.K. Abdul Azil, P.K Dharmaraj, "Ecology of Indian estuary studies on the zooplankton ecology of Kadinamkulam backwater", Science, 93, 573-584, 1984.

[2]. K. Arun Kumar, A. Hema, "Heavy metal accumulation in certain marine animals along the East coast of Chennai, Tamil Nadu, India”, Journal of Environmental Biology, 28(3), 637643, 2007.

[3]. S.A. Manjare, S.A. Vhanalakar, D.V. Muley, "Water quality assessment of Vadgaon tank of Kolhapur (Maharashtra), with special reference to zooplankton", International Journal of Advanced Biotechnology and Research, 1(2), 91-95, 2010.

[4]. B.B. Singh, R. Pandey, "Environmental studies", Ramesh Publishing House, New Delhi. 1-584, 2011.

[5]. P. Mary Helan, A. JayaSree, S. Antony Johson, J. BelshaJayaEdith, H. Chillarasu, "Seasonal variations in Physico-Chemical parameters of water in coconut Hust Retting area, Parakkani, Tamilnadu", International Journal of Environmental Science, 1(6), 1056-1061, 2011.

[6]. P.R. Jayachandran, S. Bijoy Nandan, O.K. Sree Devi, "Water quality variation and nutrient characteristics of Kodungallur Azhikode estuary Kerala, India", Indian Journal of GeoMarine Sciences, 41(2), 180-187, 2011.

[7]. S. Brinda, M. Srinivasan, S.Balakrishnan, "Studies on diversity off in fish larvae in Vellar estuary, southeast coast of India", World Journal of Fish and Marine Sciences, 2(1), 4450, 2010.

[8]. F.J.A. Oliva - Paterna, A. Andreu, P.A. Minano, D. Verdiell, A. Eqea, "Y-O-Y fish species richness in the littoral shallows of the meso - saline coastal lagoon (Mar Menor, Mediterranean coast of Iberian Peninsula)", Journal of Applied Ichthyology, 22, 235 - 237, 2006.

[9]. A.W. Paterson, A.K. Whitfield, "Do shallow - water habitats function as refugia for juvenile fishes?", Estuarine, Coastal and Shelf Science, 51, 359 - 364, 2000.

[10]. C.V. Kurian, "Contribution of estuarine biology", Bulletin Department of. Marine Sciences University of Cochin, 7, 1004, 1975.

[11]. N. Jayabalan, G.S. Thangaraj, K. Ramamurthy, "Fin fish seed resources of Vellar estuary", Symposium of Coastal Aquaculture, Abstracts, 70, Cochin, India 1980.

[12]. APHA, "Standard methods for the examination of water and wastewater", 21st Edition. American public health association,
American water works association water, Water pollution control federation, Washington, DC, 2005.

[13]. J.D.H. Strickland, T.R. Parsons, "A practical hand book of seawater analysis", Bulletin-.Fisheries Research Board of Canada, 67, 311, 1972.

[14]. F. Day, "The fishes of India, being a natural history of the fishes known to inhabit the seas and freshwaters of India", Burma and Ceylon, Quaritch, London, 1878.

[15]. F. Day, "The fishes in India, Being a natural history of the fishes known to inhabit the seas and freshwater of India", Burma, Ceylon, Jegmander Book Agency, New Delhi, 778, 1994.

[16]. M. Prema, B. Subramanian, "Hydro biological parameters of Muttukadu backwater of Bay of Bengal. Indian Hydrobiology", 6(1\&2), 95-100, 2003.

[17]. P. Damotharan, N. Vengadesh Perumal, M. Arumugam, S. Vijayalakshmi, T. Balasubramanian, "Seasonal variation of physico-chemical characteristics in point Calimere coastal waters (South East Coast of India)", Middle-East Journal of Scientific Research, 6(4), 333-339, 2010.

[18]. A. Sundaramanickam, T. Sivakumar, R. Kumaran, V. Ammaiappan, R.Velappan, "A comparative study of physicochemical investigation along Parangipettai and Cuddalore coast", Journal of Environmental Science and Technology, 1, $1-10,2008$.

[19]. S. Bikash Saha, S.B. Bhattacharya, B.K. Pandey, A. Choudhury, "Physicochemical characteristics in relation to pollution and phytoplankton production potential of a brackish water ecosystem of Sundarbans in west Bengal", Journal of Tropical Ecology, 42(2), 199-205, 2001.

[20]. P, Soundarapandian, T. Premkumar, G.K.Dinakaran, "Studies on the phyisco- chemical characteristics and nutrients in the Uppanar estuary of Cuddalore, south east coast of India", Current Research Journal of Biological Sciences, 1(3), 102105, 2009.

[21]. P.Palpandi, "Hydrobiological parameters, pollution density and distribution pattern in the gastropod Nerita (dostia) crepidularia Lamarck, 1822, from mangroves of Vellar estuary, southeast India", International Journal of Biodiversity and Conservation, 3(4), 121-130, 2011.

[22]. P. Santhanam, P. Perumal, "Diversity of zooplankton in Parangipettai coastal waters, South east coast of India", Journal of the Marine Biological Association of India, 45(2) 144-151, 2003.

[23]. S. Upadhaya, "Physico-chemical characteristics of the Mahanadi estuarine ecosystem east coast of India", Indian Journal of Marine Sciences, 17, 19-23, 1998.

[24]. T. Nedumaran, V. Ashok Prabu, P. Perumal, "Ecology of phytoplankton of Vellar estuary, southeast coast of India", Seaweed Research and Utilisation, 23(1\&2), 157- 162, 2001.

[25]. S. Nayar, G. Gowda, "Studies on phytoplankton pigments in a tropical coastal lagoon", Indian Journal of Fisheries, 46, 215229, 1999.

[26]. K.M. Rajesh, G. Gowda, M.R. Mendon, "Primary Productivity of the brackish water impoundments along Nethravathi estuary, Mangalore in relation to some physico-chemical parameters", Fishery Technology, 39, 85-87, 2002.

[27]. M.S. Hossain, N.G. Dassm, M.S.N. Chowdhury, "Fisheries Management of the Naaf river Chittan gong', Coastal and Ocean Research Bangladesh, 257, 2007.

[28]. N. Rajendran, K. Kathiresan, "Do decomposing leaves of mangroves attract fishes?", Current Science, 77, 972-976, 1999.

[29]. P.B. Durga, N. Lakshman, D.S. Satyabrata, “A check list on ichthyofanal diversity of Bahuda estuary, Odisha, east coast of 
India", International Journal of Zoological Research, 9(2), 3948, 2013.

[30]. E. Lasne, B. Bergerot, S. Lek, P. Laffaille, "Fish zonation and indicator species for the evaluation of the ecological status of rivers, example of the Loire basin (France)", River Research and Applications, 23, 877-890, 2007.

[31]. B. Bergerot, E. Lasne, T. Vigneron, P. Laffaille, "Prioritization of fish assemblages with a view to conservation and restoration on a large scale European basin, the Loire (France)", Biodiversity and Conservation", 17(9), 2247-2262, 2008.

[32]. D. Basavaraja, J.Narayana, B.R.Kiran, E.T.Puttaiah, "Fish diversity and abundance in relation to water quality of Anjanapura reservoir, Karnataka, India”, International Journal of Current Microbiology and Applied Sciences, 3(3), 747-757, 2014

[33]. S.J.M. Blaber, "Tropical Estuarine Fishes, Ecology, Exploitation and Conservation", Blackwell Science, Oxford, 372, 2000.

[34]. M.R.U. Nabi, M.A.A. Mamum, M.H.Ullah, M.G.Mustafa, "Temporal and spatial distribution of fish and shrimp assemblage in the Bakkhali river estuary of Bangladesh in relation to some water quality parameters", Marine Biology Research, 7, 436-452, 2011.

[35]. J.S. Maes, V.F. Damme, F. Meiva, Olievier, "Statistical modeling of seasonal and environmental influences on the population dynamics of an estuarine fish community" Marine Biology, 145, 103 - 342, 2004.

[36]. M. Shahadat Hossain, N. Gopal Das, S. Sarkar, M. Ziaur Rahaman, "Fish diversity and habitat relationship with environmental variables at Meghna river estuary, Bangladesh", Egyptian Journal of Aquatic Research, 38, 213-226, 2012.

[37]. E.C. Kemdirim, "Studies on the hydrochemistry of Kangimi reservoir, Kaduna State, Nigeria", African Journal of Ecology, 43, 7-13, 2005.

\section{Author's Profile:}

Dr. A. Suganthi awarded her Ph.D degree in University of Madras and Published articles in peer reviewed journals. Dr. C. Venkatraman currently working as scientist D in Zoological survey of India and awrded his Ph.D degree in Wildlife biology- Zoology by University of Madras. He published articles in National and International journals. Dr.K.Perinbam working as assistant professor in Botany, Govt Arts college Nandanam, She Published more than 40 articles in peer reviewed journals. 